\title{
Augmentation of Life Insurance Services with the Help of Information Technology Enabled Services
}

\author{
Dr. Partha Sarathi Choudhuri \\ Department of Business Administration, The University of Burdwan, West Bengal, India
}

\begin{abstract}
Globalization and emergence of information technology has changed the customers' socio-economic culture and human interactions are now significantly being replaced by the interactions of human-technology where information technology is playing the most important role in providing variety of services to the customers in order to satisfy them. Like any other companies, life insurance companies are also trying to gain the maximum utilization of the information technology in most efficient and effective way in the business operation especially at the time of delivery of different types of services to the customers in the competitive market where customers are fully aware of their needs and requirements, expectations, information technology, information technology enabled services. In the present context, the researcher in this paper tried to understand how life insurance services can be augmented with the help of information technology enabled services with special reference to the Life Insurance Corporation of India (LICI) in Burdwan district, West Bengal.
\end{abstract}

Keywords: Augmentation, Information Technology, Insurance, Service.

\section{Introduction}

In $21^{\text {st }}$ century information technology (IT) has become the backbone of every industry, especially for the service industries, all over the world. In the modern fast life, life insurance customers have not so much of time to spare with the insurer neither to understand the different life insurance policies or schemes nor to perform their different transactional operations rather they are becoming more expecting about the information technology and information technology enabled services (ITES) in their life. Information technology is not only enabling the customers to get detailed information regarding the various products and services offered by the organizations, compare the prices of the products and perform their transactional operations in a very fast and secure way but also helping the organizations to carry out their several business operations electronically successfully. After liberalization, while establishing its role in the economic development process of the country, Indian insurance market has undergone a dramatic change and also influenced the financial sector as a whole. There are now many private and foreign life insurance companies performing their operations in Indian insurance market and offering different type of products and services to the customers. The insurance companies are trying to change their focus from product orientation to customer orientation and involving in the IT investment in their business in order to survive in the long run in the competitive market through fulfilling various needs and requirements of their customers than before. The largest as well as one and only public sector life insurance company of India namely Life Insurance Corporation of India (LICI) is no exception to this. From the very early age of the business, LICI has not only implemented information technology in their operations and providing a variety of information technology enabled services to their customers but also adopted various strategies to modernize their present IT infrastructure in order to facilitate the customers in different ways in their daily life. At present, organizations also eagerly want to augment their life insurance services with the help of information technology enabled services in the most efficient and effective way in the competitive insurance market. Under the present circumstances, the current study has been conducted on the life insurance customers of all the 17 branches of the Life Insurance Corporation of India located in Burdwan district, West Bengal, to observe the present scenario of the augmentation of life insurance services with the help of information technology enabled services.

\section{Review Of Literature}

"A service is a process consisting of a series of more or less intangible activities that normally, but not necessarily always, takes place in interactions between the customer and service employees and/or physical resources or goods and/or systems of the service provider, which are provided as solutions to customer problems" (Gronroos, 2000). Service quality may be defined as "a global judgement or attitude relating to a particular service; the customer's overall impression of the relative inferiority or superiority of the organization and its services. Service quality is a cognitive judgement" (Fogli, 2006). Czepiel (1990) defined the service quality as customer perception of how well a service meets or exceeds their expectations. In simple way service quality can be described as "the degree and direction of discrepancy between customers' service perceptions and expectations" (Parasuraman and Zeithaml, 2006). Service quality dimensions are likely to be industry specific 
(Asubonteng et al., 1996). Babakus and Boller (1992) stated that dimensionality of service quality may depend on the type of service under study where the importance of different dimensions of the service quality depend on the characteristics of the industry (Brady and Cronin, 2001). As the identification of the determinants of service quality is necessary to be able to specify, measure, control and improve service quality perceived by the customer so it should be a central concern for service management, academics and practitioners (Johnston, 1995). The mostly used service quality measurement tool SERVQUAL (Parasuraman et al., 1988) consists of five dimensions namely tangibles, reliability, responsiveness, assurance and empathy and according to Oliver (1993) customer consider the expectations of performance on these service dimensions. Based on the Parasuraman et al. (1985)'s GAP model and the ten dimensions of the service quality, Zeithaml et al. (1990) developed Customer Assessment of Service Quality through which customer can access the quality of service. The six criteria of good perceived service quality identified by Gronroos (1988) are professionalism and skills, attitudes and behaviors, accessibility and flexibility, reliability and trustworthiness, recovery, and reputation and credibility. Among these professionalism and skills can be referred as technical or outcome-related dimension, attitudes and behaviors, accessibility and flexibility, reliability and trustworthiness and the recovery can be referred as functional or process-related dimensions and reputation and credulity can be referred as imagerelated dimension. Reeves and Bednar (1994) in their study asserted that excellence, value, conformance to specifications and meeting and/or exceeding expectations are the four dimensions of service quality. According to Brady and Cronin (2001)'s opinion in service marketing literature so far, the most debated and controversial topic is the conceptualization and measurement of the perceptions of service quality. Combining Nordic model (Gronroos, 1984), SERVQUAL (Parasuraman et al., 1988), three component model (Rust and Oliver, 1994) and the multilevel model (Dabholkar et al., 1996) of service quality, Brady and Cronin (2001) developed multihierarchical model where service quality includes dimensions and sub-dimensions. To investigate the SERVQUAL structure across the five service industries, Mels et al. (1997) performed the factor analysis and found two dimensions of service quality namely intrinsic and extrinsic which are linked to interactive quality (Lehtinen and Lehtinen, 1985) as well as interaction quality (Gronroos, 1990) and to the technical quality (Gronroos, 1990) respectively. "Therefore, while SERVQUAL can be used in its present form to access and compare quality across a wide variety of firms, appropriate adaptation of the instrument may be desirable when only a single service is investigated" (Parasuraman et al., 1988) and the determinants of service quality should be measured at the item level (Brady and Cronin, 2001).

Information Technology (IT) is described as any technology that helps to produce, manipulate process, store, communicate, and/or disseminate information (William and Sawyar, 2005). According to Hoffman (1994), information technology can be explained as "an all-inclusive term that encompasses computers and telecommunication in all their forms, whatever their use" (Stewart and Kleiner, 1996). Pitt et al. (1999) expressed that information technology may be considered as a platform that rides on the Internet, a hypermedia information storage system which connects computer-based resources around the world. Drucker (1993); Schultze (2000) affirmed that information technology service is knowledge work and it requires creativity as well as problem-solving abilities to produce idiosyncratic, esoteric knowledge. Bauer (2003) asserted that within an organization, individual business units started creating their information technology units because the cost of computing technology decreased and the trained information technology personnel became readily available. Shang and Seddon (2002) noted that information technology is playing an important role in attaining organizational benefits, mainly because of its ability to transform resources into core capabilities, and at times, facilitate and accelerate a change in organizational culture. Kenova and Jonasson (2006) revealed that efficiency and effectiveness are the keys to competitive advantage and business success in the age of information. Dabholkar (1996) asserted that the growth of technology-based self-services is the result of increase of labor costs and innovations in technology. The studies of Bitner et al. (2000) and Li et al. (2003) indicated that for many services in service delivery, the human interactions have become redundant due to the rise of information technologies and the internet. Meuter et al. (2000; 2005) stated that as self-service technologies are increasingly implemented in customer-firm interactions so the trend for self-service technologies will prolong. Johns et al. (2003) asserted that a significant impact on business operations had already been taken place by the e-commerce and various advances in information technology. Choudhuri (2014a) pointed out that there exists a wide scope of e-business opportunity to the every life insurance company in the present competitive life insurance market. The use of technology presents operational efficiency with additional functionality as well as the convenience (Arend, 1992). In the modern age of the society just like a catalyst the information technology has a strong influence in the improvement of the quality of services provided by the life insurers (Choudhuri, 2013a) and convenient transaction of the life insurance customers is very much depends on the modern technology namely information technology (Choudhuri, 2014b). The study of Choudhuri (2012) revealed that information technology enabled convenient services (ITECS) has emerged as the one of the important dimensions of the structure of service quality in life insurance sector and to the life insurance customers, ITECS is the third most important service quality dimension (Choudhuri and Dasgupta, 2013). Observing the role of information 
technology in fulfillment of the customers' various needs and requirements in life insurance (Choudhuri, 2014c) as well as the dependency of the life insurance customer satisfaction on the information technology (Choudhuri, 2013b) and on the perceived service quality (Choudhuri, 2014d), in life insurance industry, the organizational performance in the office operation of systems technology leaders was linked to the level of information technology investment intensity (Harris and Katz, 1991). Choudhuri (2013c) also affirmed that introduction of information technology by the Life Insurance Corporation of India is strongly related with the entry of private players in the Indian life insurance market. Charles (1993) revealed that service industries have been identified as the biggest buyers of new information technology. That's why Jen-Her and Yu-Min (2006); Leslie and Richard (2006) asserted that managers of the insurance companies are able to process work quickly as well as response to their customers has been faster and prompt using the latest information technology system.

\section{Methodology}

For the purpose of the study, researcher first of all formulated the following null and alternative hypotheses:

$\mathrm{H} 1_{0}$ : Convenience in transaction by the customer is independent of the information technology.

$\mathrm{H} 1_{\mathrm{a}}$ : Convenience in transaction by the customer is dependent of the information technology.

$\mathrm{H} 2_{0}$ : Fulfillment of customers' wishes is independent of the information technology.

$\mathrm{H} 2_{\mathrm{a}}$ : Fulfillment of customers' wishes is dependent of the information technology.

$\mathrm{H} 3_{0}$ : Perceived service quality in life insurance is independent of the information technology.

$\mathrm{H} 3_{\mathrm{a}}$ : Perceived service quality in life insurance is dependent of the information technology.

For the present study PZB's SERVQUAL model was adapted as the backbone of the survey instrument. To investigate the dimensional structure of the service quality for the Life Insurance Corporation of India, at the outset some more items related to information technology were included along with the existing 22 items of SERVQUAL instrument spread over tangibility, reliability, responsiveness, assurance and empathy dimensions. In conjunction with the other items, the importance of having information technology in LIC, convenience in transaction with the insurer and the fulfillment of LICI customers' various needs and requirements were also included in the initial questionnaire. After proper formation of survey instrument, pilot study was conducted randomly selecting 30 customers for this study where explaining objectives and purpose of the study, researcher tried to get valuable feedback from these customers. Based on this pilot study, the preliminary analysis established the internal consistency of the items within questionnaire especially the items within each dimension and identified three items under Information Technology Enabled Services. The pilot study gave the confirmation of validity and reliability of final survey instrument. Thus, the modified SERVQUAL scale was developed as the survey instrument for the customers. This modified SERVQUAL instrument consists of six dimensions named Tangibility, Reliability, Responsibility, Assurance, Empathy and Information Technology Enabled Services where Tangibility contains 5 items, Reliability contains 5 items, Responsibility contains 4 items, Assurance contains 5 items, Empathy contains 3 items and Information Technology Enabled Services contains 3 items. The questionnaire used for the study included both open-ended and close-ended and consisted seven point Likert scale ranging from 1-strongly disagree to 7-strongly agree. Using random sampling technique a total 350 questionnaires were distributed among the customers of 17 LIC branches in Burdwan district, generating 221 usable responses which were considered as the sample size for this study. According to Hair et al. (1992) for multivariate analysis the sample size should be at least 5 times the number of parameters in the model. As the proposed model of this study consists of 25 parameters, the minimum response necessary would be $\left(25^{*} 5\right)=125$. Thus, the sample size of this research, i.e., 221 in case of customers is far in excess of the Hair et al.'s (1992) recommendation as well. SPSS 16 software was used for analysis.

\section{Results And Discussions}

Based on the demographic data of the LICI customers which was collected through cross-sectional survey for the purpose of the study, the central tendency of the various demographic profiles of the customers was measured. The summarized demographic profile of the customers of the study is now given in Table 1:

Table 1: Demographic profile of the customers

\begin{tabular}{|c|c|c|c|c|c|c|}
\hline $\begin{array}{c}\text { Demographic } \\
\text { Variable }\end{array}$ & Demographic Characteristics & Frequency & Mean & Median & Mode & $\begin{array}{c}\text { Std. } \\
\text { Deviation }\end{array}$ \\
\hline \multirow{2}{*}{ Gender } & Male & $192(86.9)$ & \multirow{2}{*}{1.1312} & \multirow{2}{*}{1.0000} & \multirow{2}{*}{1.00} & \multirow{2}{*}{0.33841} \\
\hline & Female & $29(13.1)$ & & & & \\
\hline \multirow{5}{*}{ Age } & $\leq 30$ years & $51(23.1)$ & \multirow{5}{*}{2.6154} & \multirow{5}{*}{2.0000} & \multirow{5}{*}{2.00} & \multirow{5}{*}{1.26905} \\
\hline & $31-40$ years & $66(29.9)$ & & & & \\
\hline & $41-50$ years & $38(17.2)$ & & & & \\
\hline & $51-60$ years & $49(22.2)$ & & & & \\
\hline & $\geq 60$ years & $17(7.7)$ & & & & \\
\hline
\end{tabular}


Augmentation of Life Insurance Services with the Help of Information Technology Enabled Services

\begin{tabular}{|c|c|c|c|c|c|c|}
\hline \multirow{4}{*}{ Income } & $\leq$ Rs.14999.00 & $30(13.6)$ & \multirow{4}{*}{2.3529} & \multirow{4}{*}{2.0000} & \multirow{4}{*}{2.00} & \multirow{4}{*}{0.82150} \\
\hline & Rs.15000.00 -Rs.24999.00 & $102(46.2)$ & & & & \\
\hline & Rs.25000.00 -Rs.44999.00 & $70(31.7)$ & & & & \\
\hline & $\geq$ Rs. 45000.00 & $19(8.6)$ & & & & \\
\hline \multirow{5}{*}{ Occupation } & Salaried & $174(78.7)$ & \multirow{5}{*}{1.4661} & \multirow{5}{*}{1.0000} & \multirow{5}{*}{1.00} & \multirow{5}{*}{1.00226} \\
\hline & Business & $15(6.8)$ & & & & \\
\hline & Professional & $11(5.0)$ & & & & \\
\hline & Retired & $18(8.1)$ & & & & \\
\hline & Housewife & $3(1.4)$ & & & & \\
\hline \multirow{5}{*}{$\begin{array}{c}\text { Educational } \\
\text { Qualifications }\end{array}$} & High school & $14(6.3)$ & \multirow{5}{*}{3.1991} & \multirow{5}{*}{4.0000} & \multirow{5}{*}{4.00} & \multirow{5}{*}{1.08970} \\
\hline & Graduate & $56(25.3)$ & & & & \\
\hline & Post-graduate & $38(17.2)$ & & & & \\
\hline & Professional & $98(44.3)$ & & & & \\
\hline & Any other & $15(6.8)$ & & & & \\
\hline \multirow{3}{*}{$\begin{array}{c}\text { Locality of } \\
\text { Living }\end{array}$} & Center of the town & $144(65.2)$ & \multirow{3}{*}{1.5611} & \multirow{3}{*}{1.0000} & \multirow{3}{*}{1.00} & \multirow{3}{*}{0.82138} \\
\hline & Outskirts of the town & $30(13.6)$ & & & & \\
\hline & Rural areas adjoining town & $47(21.3)$ & & & & \\
\hline \multirow{2}{*}{ Modern Aids } & Mobile Phone & $64(29.0)$ & \multirow{2}{*}{1.4208} & \multirow{2}{*}{2.0000} & \multirow{2}{*}{2.00} & \multirow{2}{*}{0.90921} \\
\hline & Combination of mobile \& internet & $157(71.0)$ & & & & \\
\hline
\end{tabular}

* Percentage (\%) in parenthesis

From the available data the Rotated Component Matrix obtained the factor loading or cross-loading of the customers' items along with name of the different dimensions and the commonalities and differences of factor loading or cross loadings of the several items across different dimensions. The detail analysis is presented in Table 2 and 3.

Table 2: Rotated Component Matrix on Customers' Expectation Variables

\begin{tabular}{|c|c|c|c|c|c|c|c|}
\hline & \multicolumn{6}{|c|}{ Component } & \multirow{2}{*}{$\begin{array}{l}\text { Dimension } \\
\text { Naming }\end{array}$} \\
\hline & $\mathbf{1}$ & 2 & 3 & 4 & 5 & 6 & \\
\hline Modern Equipments & & & & & & 0.628 & \multirow{5}{*}{ Tangibility } \\
\hline Professional Appearance of Employees & & & & & & 0.888 & \\
\hline Accessible and visual display of materials & & & & & & 0.857 & \\
\hline Physical comfort level of customers & & & & & & 0.893 & \\
\hline Convenient business hours & & & & & & 0.923 & \\
\hline Fulfill promise in a timely manner & 0.748 & & & & & & \multirow{5}{*}{ Reliability } \\
\hline Error-free records & 0.684 & & & & & & \\
\hline Involvement and interest to solve a customer problem & 0.739 & & & & & & \\
\hline Provide exact information & 0.583 & & & & & & \\
\hline Perform the service right the first time & 0.625 & & & & & & \\
\hline Prompt services to the customers & & & 0.590 & & & & \multirow{4}{*}{ Responsibility } \\
\hline Willingness to help customers & & & 0.705 & & & & \\
\hline Not be ever too busy to respond & & & 0.832 & & & & \\
\hline Treat the public situation with care $\&$ seriousness & & & 0.720 & & & & \\
\hline Instill confidence in the customers & & 0.623 & & & & & \multirow{5}{*}{ Assurance } \\
\hline Safety of transactions & & 0.641 & & & & & \\
\hline Courteous with the customers & & 0.754 & & & & & \\
\hline Knowledge of employees & & 0.663 & & & & & \\
\hline $\begin{array}{l}\text { Confidentiality of Records \& Information of } \\
\text { Customers }\end{array}$ & & 0.724 & & & & & \\
\hline Individual attention to the customers & & & & & 0.605 & & \multirow{3}{*}{ Empathy } \\
\hline Understand customers' specific needs & & & & & 0.657 & & \\
\hline Customers' best interest at heart & & & & & 0.616 & & \\
\hline Electronic network & & & & 0.773 & & & \multirow{3}{*}{$\begin{array}{c}\text { Information } \\
\text { Technology } \\
\text { Enabled } \\
\text { Convenient } \\
\text { Services }\end{array}$} \\
\hline Networking of branches & & & & 0.648 & & & \\
\hline Additional Services & & & & 0.822 & & & \\
\hline
\end{tabular}

Extraction Method: Principal Component Analysis.

Rotation Method: Varimax with Kaiser Normalization. 
Table 3: Commonalities and differences of factor loadings/cross loadings on Customers' Expectation Variables

\begin{tabular}{|l|c|c|c|c|c|c|}
\hline \multirow{2}{*}{ Initial Eigenvalues } & \multicolumn{5}{|c|}{ Component } \\
\cline { 2 - 7 } & $\mathbf{1}$ & $\mathbf{2}$ & $\mathbf{3}$ & $\mathbf{4}$ & $\mathbf{5}$ & $\mathbf{6}$ \\
\cline { 2 - 7 } & $\mathbf{R E L}$ & $\mathbf{A S U}$ & $\mathbf{R E S}$ & ITECS & EMP & TAN \\
\hline $\boldsymbol{\%}$ of Variance & 4.794 & 3.589 & 3.232 & 3.083 & 2.875 & 2.431 \\
\hline Cumulative \% & 21.947 & 15.684 & 12.153 & 9.792 & 5.869 & 4.497 \\
\hline Cronbach's $\boldsymbol{\alpha}$ & 21.947 & 37.631 & 49.784 & 59.576 & 65.445 & 69.942 \\
\hline KMO measure of sampling adequacy & 0.873 & 0.768 & 0.857 & 0.732 & 0.717 & 0.892 \\
\hline
\end{tabular}

\# Legends used: REL- Reliability, ASU- Assurance, RES- Responsibility, ITECS- Information Technology Enabled Convenient Services, EMP- Empathy and TAN- Tangibility

According to Kaiser and Cerny (1979) the high shared variance and relatively low uniqueness in variance are indicated by the KMO measure for sampling adequacy $(0.888)$. The Barlett's Sphericity Test where Chi-square value is $3735.553(\mathrm{p}<0.0001)$ established that distribution is ellipsoid and amenable to data reduction.

The Rotated Component Matrix table, Table 2, shows that the values of all 25 items of the modified SERVQUAL instrument are greater than 0.5 which strongly support the recommendation of Nunnally and Bernstein (1994) about the factor loading and cross-loading. So, Table 2 established that all items of the questionnaire are properly loaded under six components. It is clear to understand that under the first component 5 items are properly loaded, 5 items are loaded under the second component, 4 items are loaded under the third component, 3 items are loaded under the fourth component, 3 items are loaded under the fifth component and 5 items are loaded under the sixth component and the names given for the dimensions of above mentioned group of items loaded under the components of 1,2,3,4,5 and 6 are respectively Reliability, Assurance, Responsibility, Information Technology Enabled Convenient Services, Empathy and Tangibility.

Table 3, shows that Initial Eigen values of Reliability, Assurance, Responsibility, Information Technology Enabled Convenient Services, Empathy and Tangibility are 4.794, 3.589, 3.232, 3.083, 2.875 and 2.431 respectively, i.e., all Initial Eigen values are greater than 1 which proves the significance of the factors. Whilst the corresponding Cronbanch's $\alpha$ values are found to be $0.873,0.768,0.857,0.732,0.717$ and 0.892 respectively establishing the reliability of the survey instrument of the study.

Parasuraman et al. (1988) suggested SERVQUAL model which consists of five dimensions namely Tangibles, Reliability, Responsiveness, Assurance and Empathy. In the present study researcher included few additional items related to the information technology enabled services in the existing SERVQUAL instrument. The above discussions establish the modification of SERVQUAL instrument for life insurance services that has six dimensions namely Reliability, Assurance, Responsibility, Information Technology Enabled Convenient Services, Empathy and Tangibility, i.e., existing among five dimensions the new dimension Information Technology Enabled Convenient Services is included in the PZB's SERVQUAL instrument.

To understand the strength of the relationship of convenient transaction of the customers and information technology, the simple regression analysis was performed in order to predict the dependent variable from the independent variable (predictor) where convenient transaction was considered as the dependent variable and information technology was considered as the independent variable for this study. The results of first simple regression analysis are given below in the following tables:

Table 4: Result of Regression Analysis 1 Variables Entered/Removed ${ }^{\mathrm{b}}$

\begin{tabular}{|c|c|c|c|}
\hline Model & Variables Entered & Variables Removed & Method \\
\hline 1 & INFORMATION TECHNOLOGY & Enter \\
\hline
\end{tabular}

a. All requested variables entered.

b. Dependent Variable: CONVENIENT TRANSACTION

Table 5: Model Summary ${ }^{b}$ (IT vs. CT)

\begin{tabular}{|c|c|c|c|c|}
\hline Model & $\mathrm{R}$ & $\mathrm{R}$ Square & Adjusted R Square & Std. Error of the Estimate \\
\hline 1 & $.166^{\mathrm{a}}$ & .028 & .023 & .98320 \\
\hline
\end{tabular}

a. Predictors: (Constant), INFORMATION TECHNOLOGY

b. Dependent Variable: CONVENIENT TRANSACTION 
Table 6: Result of ANOVA (IT vs. CT)

ANOVA $^{\mathrm{b}}$

\begin{tabular}{|c|c|c|c|c|c|c|}
\hline Model & & Sum of Squares & df & Mean Square & F & Sig. \\
\hline \multirow{3}{*}{1} & Regression & 5.989 & 1 & 5.989 & 6.196 & $.014^{\mathrm{a}}$ \\
\cline { 2 - 7 } & Residual & 211.703 & 219 & .967 & & \\
\cline { 2 - 7 } & Total & 217.692 & 220 & & & \\
\hline
\end{tabular}

a. Predictors: (Constant), INFORMATION TECHNOLOGY

b. Dependent Variable: CONVENIENT TRANSACTION

Table 7: Regression Coefficients (IT vs. CT)

Coefficients $^{\mathrm{a}}$

\begin{tabular}{|c|c|c|c|c|c|c|}
\hline & \multirow[t]{2}{*}{ Model } & \multicolumn{2}{|c|}{$\begin{array}{l}\text { Unstandardized } \\
\text { Coefficients }\end{array}$} & $\begin{array}{l}\text { Standardized } \\
\text { Coefficients }\end{array}$ & \multirow[t]{2}{*}{$\mathrm{t}$} & \multirow[t]{2}{*}{ Sig. } \\
\hline & & B & Std. Error & Beta & & \\
\hline \multirow{2}{*}{1} & (Constant) & 3.306 & .168 & & 19.734 & .000 \\
\hline & INFORMATION TECHNOLOGY & .284 & .114 & .166 & 2.489 & .014 \\
\hline
\end{tabular}

a. Dependent Variable: CONVENIENT TRANSACTION

The result of simple regression analysis shows that dependent variable convenient transaction has a strong relationship with the independent variable information technology. In ANOVA result of Table 6, the value of $F=6.196, p \leq 0.001$ established the significance of the relationship between convenience of the customer in transaction and the information technology. The result of regression coefficients in Table 7 indicates that the standardized coefficient $\beta$ and corresponding t-value of information technology are $\beta=0.166$, $\mathrm{t}=2.489, \mathrm{p}<0.001$ which also proved that there exists positive and strong relationship between dependent variable convenience of the customer in transaction and the independent variable information technology in the present study. So, here the first null hypothesis is rejected and alternative hypothesis "Convenience in transaction by the customer is dependent of the information technology" is accepted.

To realize the strength of the relationship of fulfillment of customers' wishes and information technology, the simple regression analysis was performed in order to predict the dependent variable from the independent variable (predictor) where fulfillment of customers' wishes was considered as the dependent variable and information technology was considered as the independent variable for this study. The results of second simple regression analysis are given below in the following tables:

Table 8: Result of Regression Analysis 2

Variables Entered/Removed ${ }^{\text {b }}$

\begin{tabular}{|c|c|c|c|}
\hline Model & Variables Entered & Variables Removed & Method \\
\hline 1 & INFORMATION TECHNOLOGY & Enter \\
\hline
\end{tabular}

a. All requested variables entered.

b. Dependent Variable: WISHES

Table 9: Model Summary ${ }^{\mathrm{b}}$ (IT vs. WISHES)

\begin{tabular}{|c|c|c|c|c|}
\hline Model & R & R Square & Adjusted R Square & Std. Error of the Estimate \\
\hline 1 & $.521^{\mathrm{a}}$ & .283 & .274 & .81024 \\
\hline
\end{tabular}

a. Predictors: (Constant), INFORMATION TECHNOLOGY

b. Dependent Variable: WISHES

Table 10: Result of ANOVA (IT vs. WISHES)

ANOVA $^{\text {b }}$

\begin{tabular}{|c|c|c|c|c|c|c|}
\hline Model & & Sum of Squares & df & Mean Square & F & Sig. \\
\hline \multirow{3}{*}{1} & Regression & 23.758 & 1 & 23.758 & 36.217 & $.007^{\mathrm{a}}$ \\
\cline { 2 - 7 } & Residual & 280.101 & 219 & 1.279 & & \\
\cline { 2 - 7 } & Total & 303.859 & 220 & & & \\
\hline
\end{tabular}

a. Predictors: (Constant), INFORMATION TECHNOLOGY

b. Dependent Variable: WISHES

Table 11: Regression Coefficients (IT vs. WISHES)

Coefficients $^{\text {a }}$

\begin{tabular}{|c|c|c|c|c|c|c|}
\hline & \multirow[t]{2}{*}{ Model } & \multicolumn{2}{|c|}{$\begin{array}{c}\text { Unstandardized } \\
\text { Coefficients }\end{array}$} & $\begin{array}{c}\text { Standardized } \\
\text { Coefficients }\end{array}$ & \multirow[t]{2}{*}{$\mathrm{t}$} & \multirow[t]{2}{*}{ Sig. } \\
\hline & & $\mathrm{B}$ & Std. Error & Beta & & \\
\hline \multirow{2}{*}{1} & (Constant) & 2.617 & .183 & & 9.183 & .000 \\
\hline & INFORMATION TECHNOLOGY & .149 & .074 & .465 & 3.721 & .004 \\
\hline
\end{tabular}

a. Dependent Variable: WISHES 
The result of simple regression analysis indicates that dependent variable fulfillment of customers' wishes has a strong relationship with the independent variable information technology. In ANOVA result of Table 10, the value of $\mathrm{F}=36.217, \mathrm{p} \leq 0.001$ established the significance of the relationship between fulfillment of customers' various wishes and the information technology. The result of regression coefficients in Table 11 shows that standardized coefficient $\beta$ and corresponding t-value of the information technology are $\beta=0.465$, $\mathrm{t}=3.721, \mathrm{p}<0.001$ which also proved that there exists positive and strong relationship between dependent variable fulfillment of customers' various wishes and the independent variable information technology in the current study. So, in this study the second null hypothesis is rejected and alternative hypothesis "Fulfillment of customers' wishes is dependent of the information technology" is accepted.

To examine the strength of the relationship of perceived service quality and information technology, simple regression analysis was performed to predict the dependent variable from the independent variable (predictor) where perceived service quality (which is the mean score of all the customers' perception of service quality) was considered as a dependent variable and the information technology was considered as an independent variable for the study. The results of third simple regression analysis are given below in the following tables:

Table 12: Result of Regression Analysis 3 Variables Entered/Removed $^{\text {b }}$

\begin{tabular}{|c|c|c|c|}
\hline Model & Variables Entered & Variables Removed & Method \\
\hline 1 & INFORMATION TECHNOLOGY & Enter \\
\hline
\end{tabular}

a. All requested variables entered.

b. Dependent Variable: PERCEIVED SERVICE QUALITY

Table 13: Model Summary ${ }^{b}$ (IT vs. PSQ)

\begin{tabular}{|c|c|c|c|c|}
\hline Model & $\mathrm{R}$ & R Square & Adjusted R Square & Std. Error of the Estimate \\
\hline 1 & $.542^{\mathrm{a}}$ & .293 & .281 & .72351 \\
\hline
\end{tabular}

a. Predictors: (Constant), INFORMATION TECHNOLOGY

b. Dependent Variable: PERCEIVED SERVICE QUALITY

Table 14: Result of ANOVA (IT vs. PSQ)

ANOVA $^{\text {b }}$

\begin{tabular}{|c|c|c|c|c|c|c|}
\hline \multicolumn{2}{|c|}{ Model } & Sum of Squares & df & Mean Square & $\mathrm{F}$ & Sig. \\
\hline \multirow{3}{*}{1} & Regression & .648 & 1 & .648 & 10.238 & $.005^{\mathrm{a}}$ \\
\hline & Residual & 59.152 & 219 & .270 & & \\
\hline & Total & 59.800 & 220 & & & \\
\hline
\end{tabular}

a. Predictors: (Constant), INFORMATION TECHNOLOGY

b. Dependent Variable: PERCEIVED SERVICE QUALITY

Table 15: Regression Coefficients (IT vs. PSQ)

Coefficients $^{\mathrm{a}}$

\begin{tabular}{|c|c|c|c|c|c|c|}
\hline & \multirow[t]{2}{*}{ Model } & \multicolumn{2}{|c|}{$\begin{array}{c}\text { Unstandardized } \\
\text { Coefficients }\end{array}$} & $\begin{array}{c}\text { Standardized } \\
\text { Coefficients }\end{array}$ & \multirow[t]{2}{*}{$\mathrm{t}$} & \multirow[t]{2}{*}{ Sig. } \\
\hline & & $\mathrm{B}$ & Std. Error & Beta & & \\
\hline \multirow{2}{*}{1} & (Constant) & 4.623 & .168 & & 27.552 & .000 \\
\hline & INFORMATION TECHNOLOGY & .128 & .115 & .304 & 9.113 & .005 \\
\hline
\end{tabular}

a. Dependent Variable: PERCEIVED SERVICE QUALITY

The result of simple regression analysis indicates that dependent variable perceived service quality has a strong relationship with the independent variable information technology, i.e., prediction of dependent variable has successfully been done by the independent variable. In ANOVA result of Table 14, the value of $\mathrm{F}=10.238$, $\mathrm{p} \leq 0.001$ established the significance of the relationship between perceived service quality and information technology. The result of regression coefficients in Table 15 shows that the standardized coefficient $\beta$ and corresponding $\mathrm{t}$-values of information technology are $\beta=0.304, \mathrm{t}=9.113, \mathrm{p}<0.001$ which also proved that there exists positive and strong relationship between dependent variable perceived service quality and the independent variable information technology in the present study. So, the third null hypothesis is rejected here and alternative hypothesis "Perceived service quality in life insurance is dependent of the information technology" is accepted. 


\section{Conclusions}

The objective of the current study was to study the augmentation of life insurance services with the help of information technology enabled services with special reference to the Life Insurance Corporation of India and for this purpose the researcher initially performed the factor analysis in which Information Technology Enabled Convenient Services (ITECS) dimension revealed as one of the most important dimensions of the service quality structure for the life insurance services. The acceptance of first, second and third alternative hypotheses not only described the perfect positive linear relationship of dependent and independent variables of the study but also established the dependency of convenient transaction of the customers on the information technology, dependency of fulfillment of the various needs of the customers on the information technology and the dependency of perceived service quality on the information technology in the present context of the study. So, the study suggested that the augmentation of life insurance services can only be possible with the help of information technology enabled convenient services if the insurance company develops their attractive and easily accessible official website where accurate and up to date information would be uploaded on regular basis, through e-mail and/or SMS customers would be well informed about the newly launched policies and schemes of the insurer as well as the customer would be made aware of their different transactional matters, without facing any problem customers would be able to perform their safe and fast transactional operations in an error free manner from every part of the geographical area of the network. Thus, it may be concluded that after proper augmentation of life insurance services with the help of information technology enabled services, life insurance companies would be able to provide better quality of services to the customers according to their ideal services through its effective manpower and would be in a position to utilize the wide scope of e-business opportunities in the wider life insurance market.

\section{References}

[1] Arend, M. (1992). Technology: Ally or enemy of customer service? ABA Banking Journal, 84(9), 88-91.

[2] Asubonteng, P., McCleary, K. J., \& Swan, J. E. (1996). SERVQUAL, revisited: A critical review of service quality. Journal of Services Marketing, 10, 62-81.

[3] Babakus, E., \& Boller, G. W. (1992). "An empirical assessment of the SERVQUAL scale”. Journal of Business Research, Vol. 24, pp. 253-268

[4] Bauer, B. T. (2003). "Is a centralized or decentralized IT organization better?" Darwin Magazine. October.

[5] Bitner, M.J., Brown, S.W. \& Meuter, M.L. (2000). "Technology infusion in service encounters", Journal of the Academy of Marketing Science, Vol. 28 No. 1, pp. 138-49.

[6] Brady, M. K., \& Cronin, J. J. (2001). "Some new thoughts on conceptualizing perceived service quality: A hierarchical approach". Journal of Marketing, 65, 34-50.

[7] Charles, S. (1993). "Conceptualizing services sector productivity", Social and Economic Studies, Vol. 42 No. 4, pp. $95-113$.

[8] Choudhuri, P. S. \& Dasgupta, T. (2013). "Relative Importance of Service Quality Dimensions from Life Insurance Customers' Perspective: A Study on Life Insurance Corporation of India, Burdwan”, SIT Journal of Management, Vol. 3, No. 1 (June), pp. 258272.

[9] Choudhuri, P. S. (2012). "Dimensional Structure of Service Quality for Life Insurance: A Study of Life Insurance Corporation of India in Burdwan", Journal of Business Management, Commerce \& Research, Vol. 1, No. 3 (December), pp. 60-70.

[10] Choudhuri, P. S. (2013a). "Dependency of perceived service quality on the information technology in Life Insurance Corporation of India in Burdwan", International Journal of Scientific Research, Vol. 2, No. 11 (November), pp. 59-61.

[11] Choudhuri, P. S. (2013b). "Dependency of customer satisfaction on the information technology in Life Insurance Corporation of India", International Journal of Research in Management \& Technology, Vol. 3, No. 6 (December), pp. 153-159.

[12] Choudhuri, P. S. (2013c). "Introduction of information technology in Life Insurance Corporation of India vis-à-vis entry of private insurers in Indian life insurance market", SIT Journal of Management, Vol. 3, No. Special (November), pp. 64-74.

[13] Choudhuri, P. S. (2014a). "Scope of e-business opportunity in life insurance sector: A study on Life Insurance Corporation of India", South Asian Journal of Marketing \& Management Research, Vol. 4, Issue 3 (March), pp. 95-106.

[14] Choudhuri, P. S. (2014b). "Information technology in convenient transaction of the LICI customers", International Journal of Management, IT and Engineering, Vol. 4, No. 2 (February), pp. 388-395.

[15] Choudhuri, P. S. (2014c). "Information technology in fulfillment of the various needs of the LICI customers", Zenith International Journal of Business Economics \& Management Research, Vol. 4, No. 2 (February), pp. 203-210.

[16] Choudhuri, P. S. (2014d). "Dependency of customer satisfaction on the perceived service quality in Life Insurance Corporation of India”, Research Revolution, Vol. 2, No. 4 (January), pp. 7-9.

[17] Czepiel, J. A. (1990). Service encounters and service relationships: Implications for research. Journal of Business Research, Vol. 20 No. 1, pp. 13-21.

[18] Dabholkar, P., Thorpe, D., \& Rentz, J. (1996). A measure of service quality for retail stores: Scale development and validation. Journal of the Academy of Marketing Science, 24, 3-16.

[19] Dabholkar, P.A. (1996). "Consumer evaluations of new technology-based self-options: An investigation of alternative models of service quality", International Journal of Research in Marketing, Vol. 13 No. 1, pp. 29-52.

[20] Drucker, P. (1993). Post-Capitalist Society, NY: Harper Collins.

[21] Fogli, L. (2006). Customer Service Delivery. San Francisco: Jossey-Bass.

[22] Gronroos, C. (1984). "A Service Quality Model and Its Marketing Implications," European Journal of Marketing, (18), 36-44.

[23] Gronroos, C. (1988). Service quality: The six criteria of good perceived service. Review of Business, 9, 10-13.

[24] Gronroos, C. (1990). Service Management and Marketing, Lexington Books, Lexington, MA

[25] Gronroos, C. (2000). Service Management and Marketing: A Customer Relationship Management Approach. $2^{\text {nd }}$ ed. West Sussex: John Wiley \& Sons, Ltd.

[26] Hair, J.F., Anderson, R.E., Tatham, R.L. \& Black, W.C. (1992). 'Multivariate Data Analysis with Readings', $6^{\text {th }}$ edition, Macmillan Publishing Company, New York. 
[27] Harris S. E. \& Katz J. L. (1991). Firm size and Information Technology Investment Intensity of Life Insurers. Special Issue: Strategic use of Information Systems, MIS Quarterly, 15(3), 333-352.

[28] Hoffman, G. M. (1994). The Technology Payoff: How to Profit with Empowered Workers in the Information Age. New York, NY: Irwin, Burr Ridge.

[29] Jen-Her Wu. \& Yu-Min Wang. (2006). Measuring ERP success: the ultimate users' view. International Journal of Operations \& Production Management, 26, 8, 882-903.

[30] Johns, S. K., Smith, L. M., \& Strand, C. A. (2003). How culture affects the use of information technology. Accounting Forum (Blackwell), 27(1), 84-109.

[31] Johnston, R. (1995). The determinants of service quality: Satisfiers and dissatisfies. International Journal of Service Industry Management, 6, 53-71.

[32] Kaiser, H.F. \& Cerny, B.A. (1979). "Factor analysis of the image correlation matrix". Educational and psychological measurement, Vol. 39 No. 4, pp. 711-714

[33] Kenova, V., \& Jonasson, P. (2006). Quality online banking services. Unpublished doctoral dissertation, Jonkoping University.

[34] Lehtinen, U., \& Lehtinen, J. R. (1985). "Service Quality: A Study of Quality Dimensions", paper read at Second World Marketing Congress, University of Stirling, Scotland.

[35] Leslie P. W. \& Richard S. (2006). The role of the CIO and IT function in ERP. Communications of the ACM, 43, 4, 32-38.

[36] Li, Y.N., Tan, K.C. \& Xie, M. (2003). "Factor analysis of service quality dimension shifts in the information age", Managerial Auditing Journal, Vol. 18 No. 4, pp. 297-302.

[37] Mels, G., Boshoff, C., \& Nel, D. (1997). The dimensions of service quality: The original European perspective revisited. Service Industries Journal, 17, 173-189.

[38] Meuter, M.L., Bitner, M.J., Ostrom, A.L. and Brown, S.W. (2005). "Choosing among alternative service delivery modes: an investigation of customer trial of self-service technologies", Journal of Marketing, 69(2), pp. 61-83.

[39] Meuter, M.L., Ostrom, A.L., Roundtree, R.I. \& Bitner, M.J. (2000). "Self-service technologies: understanding customer satisfaction with technology-based service encounters", Journal of Marketing, Vol. 64 No. 3, pp. 50-65.

[40] Nunnally, J. C., \& Bernstein, I. H. (1994). Psychometric Theory (3 ${ }^{\text {rd }}$ ed.). New York: McGraw-Hill, Inc.

[41] Oliver, R. L. (1993). "A conceptual model of service quality and service satisfaction: compatible goals, different concepts", Advances in Service Marketing and Management, Vol. 2, pp. 65-85.

[42] Parasuraman, A., \& Zeithaml, V.A. (2006). Understanding and improving service quality: A literature review and research agenda in B. Weitz and R. Wensley (Ed.), Handbook of Marketing, London: Sage Publications.

[43] Parasuraman, A., Zeithaml, V.A. \& Berry, L.L. (1985). "A Conceptual Model of Service Quality and Its Implications for Future Research," Journal of Marketing 49 (Fall), 41-50.

[44] Parasuraman, A., Zeithaml, V.A. \& Berry, L.L. (1988). "SERVQUAL: A Multiple- Item Scale for Measuring Customer Perceptions of Service Quality," Journal of Retailing, 64 (Spring), 12-40.

[45] Pitt L., Berthon, P. \& Watson, R.T. (1999). "Cyber service: taming service marketing problems with the World Wide Web", Business Horizons, Vol. 42 No. 1, pp. 11-18.

[46] Reeves, C.A. \& Bednar, D.A. (1994). Defining quality: Alternatives and implications. Academy of Management Review, 19(3), 419-446.

[47] Rust, R. T., \& Oliver, R. L. (1994). Service Quality: New directions in theory and practice. Thousand Oaks, CA: SAGE Publications.

[48] Schultze, U. (2000). “A confessional account of an ethnography about knowledge work,” MIS Quarterly (24)1, pp. 3-41.

[49] Shang, S., \& Seddon, P. (2002). Assessing and managing the benefits of enterprise systems: The business manager's perspective. Information Systems Journal, 12(4), 271-299.

[50] Stewart, G. R., \& Kleiner, B. H. (1996). "The enabling power of teams and information technology". Team Performance Management, 2 (2), pp. 13-18.

[51] William, B.K., \& Sawyar S.C. (2005). "Using Information Technology". $6^{\text {th }}$ edition, McGraHill Publishing Co. U.S.A, pp. 3, 4, 147.

[52] Zeithaml, V.A., Parasuraman, A., \& Berry, L.L. (1990). Delivering quality service: Balancing customer perceptions and expectations. New York, NY: The Free Press. 